\title{
VESTIGIOS, Un viaje hacia el
}

\section{caosmos}

\author{
Dr. José Alberto de la Fuente A.*
}

\section{Resumen:}

En el presente trabajo, se dialoga con la obra y el pensamiento poético de Affonso Romano de Sant'Anna. Sus propósitos son: situar al poeta en la tradición de la poesía brasileña del siglo XX; analizar y valorizar su obra Vestigios (2005) en el marco de su pensamiento y crítica de arte e invitar al lector a "viajar" por las convergencias temáticas que se van reconociendo en la diversidad de motivos que se cruzan en los poemas del libro. Tiempo, vida y muerte, identidad, amor, conocimiento, trascendencia religiosa, naturaleza de la historia, política, arte contemporáneo y poesía concurren en la diversidad de perspectivas del hablante lírico. Se requiere verificar la siguiente hipótesis: Vestigios, obra de madurez y síntesis de un proyecto literario, constituye una epifanía que entrega señales y gestos por cambiar las condiciones de un mundo harapiento, incierto y aturdido por su errático avance científico y técnico. Se refrenda una epistemología enraizada en el caosmos de un "proyecto poético pensante" desarrollado en un periodo histórico que careció de una auténtica pedagogía del mirar.

Palabras clave: vestigio, poesía, epifanía, caosmos, crítica, epistemología enraizada

\section{Abstract:}

In the present article, the author engages in a dialog with the poetic work and the thought of Affonso Romano de Sant'Anna. His intentions are: to place the poet in the tradition of Brazilian poetry from the XX century; to analyze and to value his work Vestiges (2005) within the framework of this thought and art criticism and to invite the reader "to travel" through the thematic convergences that are being cleared up in the diversity of reasons overlapping in the poems of the book. Time, life and death, identity, love, knowledge, religious importance, nature of history, politics, contemporary art and poetry concur in the diversity of perspectives of the lyrical speaker. The author aims at verifying the following hypothesis: Vestiges, work of maturity and synthesis of a literary project, constitutes and epiphany that signals and gestures to change the conditions of an uncertain and ragged world, stunned by its erratic scientific and technical progress. An epistemology is proposed rooted in the "chaosmos" of a "thinking poetic project" developed in a historical period that lacked an authentic pedagogy of noticing.

Key words: vestige, poetry, epiphany, chaosmos, criticism, rooted epistemology

* Doctor en Literatura. Académico del Departamento de Humanidades, UCSH. jsdelafuente@ucsh.cl. Texto base de conferencia dictada en el Primer Capítulo del Corredor de las Poéticas del Sur, Facultad de Letras de la Universidad de Córdoba, Argentina (octubre 2008). 
"Nunca sabremos qué es el hombre si no lo pensamos poéticamente"

\section{Introducción}

Del diálogo con la obra Vestigios (2005) de Affonso Romano de Sant'Anna, quisiera compartir la conmoción emocional e intelectual que me ha causado cada uno y el conjunto de los 147 poemas que componen el libro. Dada la alta exigencia del hablante lírico que ilumina cada texto, anticipo que no hay poemas que desciendan de su nivel de excelencia a una escala inferior.

Excúseme el lector si el párrafo anterior constituye un juicio adelantado, excluyente de cualquier otra posibilidad de acercamiento. Por el contrario, el decoro estético de Vestigios, no permite presuponer que sus poemas nos ayuden a validar una determinada teoría en función de un método académico que busca "resultados". Cuando leía y releía cada poema, fui teniendo en mente los dos volúmenes de su Poesía reunida (1965-1999), una antología publicada en Chile 1 y demás escritos sobre arte que han llegado a mis manos. Vestigios es, sin duda, un libro de madurez, del cual es posible inferir y diseñar una nueva herramienta para seguir reclamando con urgencia la presencia de la poesía en medio de la incertidumbre de la sociedad posmoderna antecedida de un siglo XX que puso a prueba la sobrevivencia de todas las formas de vida en el planeta. Esta herramienta, a mi modo de ver, es una hermenéutica que se configura al interior de un "proyecto poético pensante" que Affonso Romano de Sant'Anna le atribuye a Carlos Drummond de Andrade toda vez que analiza y se refiere a su poesía. Este proyecto es una práctica de lectura, una capacidad de observación micro y macroscópica, una nueva

El hombre bomba (2005), antología. Santiago, Editorial Chile Poesía, coedición con Embajada de Brasil. 38 poemas traducidos por Ana Lía Torre, Washington Benavides, María Tecla, Manuel Graña, Nahuel Santana y Adán Méndez. 
epistemología que no se ahoga en la lógica de la racionalidad positivista y a la vez un método que facilita entrar y viajar por su caosmos ${ }^{2}$. Affonso Romano de Sant'Anna, en su artículo "Donde el nudo fue dato"3 (2002) piensa que toda epistemología plantea la exigencia de reconocer un lugar de enunciación porque nuestros pensamientos y gestos nacen enraizados. Para fundar un proyecto estético, es fundamental comprender que la posibilidad del entendimiento, de sus alcances y posibilidades reside en la disposición y capacidad para acordar el significado y trascendencia de las palabras. Para argumentar, recoge la evidencia del lenguaje como forma de figuración, sabiendo ponderar las dualidades y aceptar el arraigo, habitar y continuar en el verdadero territorio del arte, en "la tercera orilla del río" que imaginó João Guimarães Rosa.

Otro de los propósitos de este trabajo es compartir las convergencias temáticas que se dan en la diversidad de motivos que se cruzan en Vestigios, agrupando azarosamente los poemas de acuerdo a los siguientes desplazamientos:1) el tiempo; 2) la vida y la muerte; 3) la identidad; 4) el amor; 5) el conocimiento; 6) la trascendencia religiosa; 7) la naturaleza de la historia; 8) la política en tolerancia y solidaridad; 9) el arte contemporáneo y 10) la poesía. Quisiera verificar que esta obra constituye una epifanía que deja señales y gestos para cambiar el derrotero de un mundo harapiento, incierto y aturdido por su propio avance científico y técnico. Epifanía como momento de madurez literaria y visión de mundo, que por acumulación y síntesis permite captar lo esencial de un proyecto literario. Para este menester es oportuno conocer algo de la vida del poeta en función de su pensamiento y de su capacidad para captar la realidad en sus contradicciones, lamentos y anhelos.

Vestigios es como la erupción de un volcán que esperó mucho tiempo conteniendo sus bramidos subterráneos, dando cuenta de su existir a través de una tenue y anillada fumarola que hoy se expande por el territorio de América Latina.

\section{Un poeta de dos siglos}

Affonso Romano de Sant'Anna, nace el 27 de marzo de 1937 en la ciudad de Belo Horizonte. Su infancia es la de un niño pobre; desde su adolescencia debe trabajar para costear sus estudios. Sus padres, perte-

2 En general, entiéndase caosmos como lo primordial incubado en los universos caóticos ordenados humanamente al interior de los poemas que otorgan un sentido dialéctico al mundo percibido-creado por el hablante lírico. El arte rescata el caos, la confusión (cósmica) y lo integra al cosmos proponiendo un caosmos.

3 El artículo aparece antologado en Descontruir a Duchamp, arte na hora da revisão (2003), Rio de Janeiro, Vieira \& Lent Casa editorial Ltda, páginas 145-147. 
necientes a la religión protestante, desde muy temprano lo orientan para ser pastor. A los 17 años predica en Minas Gerais, visita favelas, cárceles y hospitales. Esta experiencia en el mundo de los carenciados y de la gente más sufrida, influirá en el estilo y temas de su poesía.

En 1956 se inserta en sendos movimientos culturales de vanguardia y por su voz de barítono participa en la obra "Madrigal Renacentista" regida por el maestro Isaac Karabtchevsky. En 1963, en la ciudad de Belo Horizonte, siguiendo la tradición de los Modernitas de 1922 de São Paulo, surge la posibilidad de convocar a diferentes grupos y tendencias de escritores. En el mes de agosto, Affonso Romano de Sant'Anna difundirá junto a Olívio Tabares de Araújo, Haroldo de Campos y escritores del grupo "Tendencia", el Comunicado y Conclusiones de la Semana Nacional de Poesía de Vanguardia. Era la época del gobierno de João Goulart, de las "reformas de base" y del auge de la utopía de la revolución cubana. El encuentro se deriva del diálogo entre los escritores mineros y los poetas concretistas con base en el Segundo Congreso Brasileño de Crítica e Historia Literaria acaecido en 1961. El Comunicado y Conclusiones, contenía lo siguiente: en primer lugar, para el desarrollo y avance de la poesía brasileña es imprescindible tener conciencia de la creación de nuevas formas, en su función creativa en el ámbito nacional e internacional. En segundo lugar, comunicación y participación situada en el lenguaje materializado en el poema y demás medios de divulgación. En tercer lugar, función práctica de la poesía cotejada con la realidad nacional y la invención de nuevos métodos para difundir textos orales, visuales, escritos y musicalizados. Y en cuarto lugar, definir la responsabilidad del escritor ante su época y ante la sociedad de la que forma parte, exigiéndose en la utilización de un lenguaje (del juego y de la tribu) como instancia valorativa, estética y éticamente significativa que evite la alienación de la conciencia social. El poeta debe contribuir a la transformación de la realidad nacional basado en el modo de ser específico de la poesía como acto creador ${ }^{4}$.

En 1965, Affonso Romano de Sant'Anna publica su primer libro de poesía, Canto y palabra y el mismo año, impelido por la dictadura, viaja a California (USA) a trabajar como profesor. A partir de 2004, el público brasileño podrá leer 9 de sus libros en los volúmenes 1 y 2 de su Poesía Reunida 1965-1999, en los cuales se incluyen Canto y Palabra (1965), Poesía sobre Poesía (1975, El gran pregón del indio Guaraní (1978), Qué país es este (1980), Política y pasión (1984), La catedral de Colonia (1985), El lado izquierdo de mi pecho, libro de aprendizaje (1992), Testamentos (1999). En 1984, en el periódico "Jornal do Brasil", asume la columna que escribía Carlos Drummond de Andrade, publicando sus poemas en las páginas políticas

4 Cf. el Comunicado sobre la "Semana Internacional de la Poesía de Vanguardia", páginas 128-130, en Música Popular e Moderna Poesia Brasileira, cuarta edición, São Paulo, Editora Landmark, 2004. 
más que en las literarias. Llamarán la atención los poemas "La implosión de la mentira" y "Sobre la actual vergüenza de ser brasileño". El balance del siglo pasado lo hace en la antología Epitafio para el siglo XX:

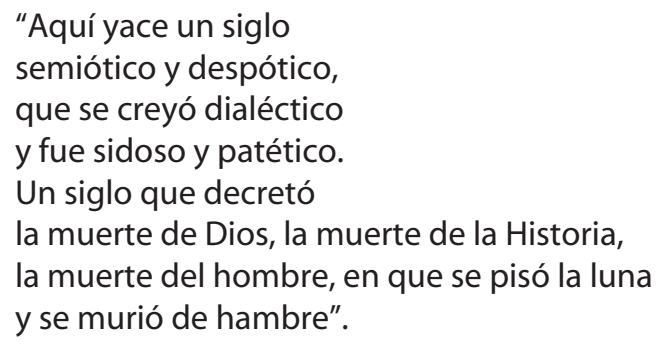

Affonso Romano de Sant'Anna es un poeta y teórico del arte y la literatura que pertenece a dos mundos discursivos y sociales porque proviene de la generación de Drummond de Andrade, la cual tuvo la genialidad de relevar un proyecto cultural asociado a personalidades de la literatura, la arquitectura y las artes plásticas como Mario de Andrade, Niemeyer, Villa-Lobos, Anita Malfatti, Portinari, Gilberto Freire, Graciliano Ramos, Jorge Amado, etc. Estos nombres forman parte de la llamada Modernidad que comienza a balbucir en los años 60 del siglo XIX y alcanzará a tener honda influencia hasta mitad del siglo XX. En ellos predomina un proyecto de país de características integradoras, utópicas, cuya conciencia crítica constituye el signo de apropiación de una identidad mestiza con sentido histórico en el tiempo y el espacio. Poeta de dos mundos porque ningún lenguaje estético le es ajeno; poesía de cordel y música popular, traspasan lo soñado y lo vivido durante la segunda mitad del siglo, atento a los orígenes de la Samba, el Ufanismo de Ari Barroso, la generación del 45, el Tropicalismo, las poéticas del Centramiento y del Descentramiento, del interregno de la música popular con Chico Buarque y las posvanguardias hasta observar las acciones de los marginales que inauguran el siglo XXI, etc. No hay duda que Affonso Romano de Sant'Anna "es recurrente en marcar el territorio de la poesía y del poeta. Traza una línea divisoria entre los discursos centrales y los periféricos. La realidad latinoamericana signada por la violencia, aterra y genera poesía, un verso marginal, muchas veces sometido a la persecución"5. El "acá" es el centro para quienes ven el Tercer Mundo desde la orilla del Norte; el "allá" es la periferia donde habita "el nosotros". 


\section{La poesía y el arte germinan con los pies en la tierra}

De los textos que he tenido a mi alcance para acercarme a la vida y obra de Affonso Romano de Sant'Anna con la intención de arribar analógicamente al corazón de Vestigios y aportarle al lector algunos atisbos de su pensamiento y conciencia estética, está su recopilación de artículos de prensa donde revisa el estado del arte contemporáneo a través de las repercusiones que produjeron las ondas concéntricas de la "espectacular" obra de Marcel Duchamp. Quien desee profundizar en ellos, se dará cuenta de que aquí se argumenta sobre un concepto de arte, la función de la crítica y las características del arte de los últimos cien años: repetición, dislocamiento, ritualización, automatismo, novedolatría, etc. El contexto histórico es el de un siglo XX generador de violencia, que termina con "anomia estética" tratando de probar tres teorías: la marxista, la psicoanalítica y la del arte contemporáneo. Esta experiencia basada en la violencia elevada a expresión artística, equívoco que se inició confundiendo lo privado con lo público, la intimidad con la creatividad, deja una inmensa tarea de restitución y rectificación: inventar una nueva "pedagogía del mirar", resituar el lugar de enunciación de la palabra poética allí donde la tradición y el futuro, el presente y el pasado inmediato, no son antinomias, sino vasos comunicantes de los nuevos discursos y de la recuperación de valores que no desconocen la historia y que tampoco rehúyen la importancia de la memoria. Affonso Romano de Sant'Anna señala que se llegó a este resultado porque los artistas no pudieron evitar la "alucinación crítica [...] que se produce cuando una obra no coincide con la teoría del artista [...] convirtiéndose las obras en instalaciones verbales paralelas" ${ }^{\prime \prime}$. En efecto, la función de la crítica debe ser un ejercicio de lectura visionaria como si fuera la primera vez que uno está frente a una obra de arte; lectura que debe confrontarse con la tradición. "La mejor crítica no es aquella que inventa el objeto de estudio y progresa en su conocimiento, sino que se torna un objeto crítico irreversible, que la crítica posterior tendrá que enfrentar para poder también avanzar"7.

En la crónica "El pastiche del caos", se infiere que en la posmodernidad se vive en la anomia ética y estética que se plasma en el pastiche y en el kitsch, arte del capitalismo que avanza ciegamente hacia la sociedad de consumo y del pensamiento único, de la imagen televisiva, del vacío existencial, reinado de la obsolescencia, de la falta de individualidad e

6 De Sant'Anna, Affonso Romano (2003): Desconstruir Duchamp, arte na hora da revisão, página 61.

7 Op., Cit., página 175. La traducción es mía. 
identidad transformada en máscara. La ideología de la globalización engulle sin misericordia todo lo que no se parezca al ilusionismo y al autoengaño. En este contexto aparecen los artistas y los poetas auténticos y los sintomáticos. Los primeros construyen un lenguaje ordenador del caos, son los alejados de los muros de la globalización, los expulsados de la república. Los segundos, son aquellos que reproducen los vicios de su tiempo, hijos adoptivos de la sociedad del espectáculo, representantes directos de la anomia ética y estética. Los poetas sintomáticos conforman la versificación tanática de la cultura; aceptan sin más la decadencia y la muerte de Dios, del hombre, del arte, del sujeto y de la historia. Los poetas auténticos "captan las señales de su tiempo, y transforman la tempestad y los rayos en energía, generada en la industria creativa [...]; los demás sólo se dejan abatir, se pulverizan como decía Heidegger en el sin-sentido de la ciudad de su tiempo. Por ahora, los artistas puramente sintomáticos se entregan al caos, el artista auténtico delante de la negatividad del caos y del orden del cosmos, crea el caosmos. En esta dirección, el desafío común que veo para los intelectuales y artistas chilenos y brasileños es claramente este: proceder a la revisión urgente no sólo de la década del 60 , sino también de la modernidad y de la posmodernidad, no con los pies regresando al siglo XIX, sino con los pies en el siglo XXI. Una revisión sin piedad, que siendo una autocrítica, sea un enfrentamiento con los ídolos de ayer, porque el mayor homenaje que se puede hacer a un contestatario de ayer es contestándole hoy"8.

Para Affonso Romano de Sant'Anna, la vida es imposible sin poesía. A través de ella descubre que siente y piensa, que la poesía ilumina su trayectoria y su pasado, que poesifando se siente menos perdido en medio de la "penumbra histórica". La poesía es una necesidad visceral, un soñar despierto y por escrito 9 . Respecto a la preocupación de las formas en poesía, en el "Soneto de la rosa" (1994), sentencia: "el poeta realiza la teoría y la práctica del soneto, convenciéndose de que no hay formas agotadas sino personas agotadas ante ciertas formas" En las conclusiones del VI volumen A Literatura no Brasil (1996), Afrânio Coutinho y Eduardo de Faria, sitúan al poeta en el ámbito de la independencia literaria y de la literatura emancipada con identidad nacional.

Al caosmos se ingresa con los pies en la tierra y la mirada en el porvenir. Con la síntesis ideológica sobre el arte y la poesía que el mismo poeta nos proporciona, en adelante veremos que todo confluye en Vestigios a través de poemas epigramáticos y poemas largos y casi narrativos donde

8 Romano de Sant'Anna, Affonso (2005): Brasil-Chile"Ontem e Hoje" (conferencia en CEPAL 12 de julio de 2005). Aparece en Revista de Literatura y Lingüistica, $N^{\circ} 16, \mathrm{UCSH}$, Chile, página 330. La traducción es mía.

9 Cf.entrevista publicada virtualmente en "Bafafá" on line, 2004, página 2: www.bafafa. com.br 
una voz indirecta obliga a que el hablante lírico habitual recurra a nuevos argumentos. Sólo los poetas de oficio pueden sostener el ritmo que hay en el libro y con esta forma de versificar, se sensibiliza la conciencia del lector para salvaguardar con optimismo el destino de la humanidad.

\section{Viaje hacia el caosmos}

El crítico José María Pereira, en los comentarios de solapa que hace a Vestigios, elogia la capacidad de comunicación que posee el conjunto de los poemas que componen el libro. No hay visos de opacidad ni de hermetismo como suele suceder con la poesía psicologista por carecer de equilibrio entre sentimiento e imagen o por el predominio desproporcionado de uno de los dos. Según Benedetto Croce, los poemas para ser buenos tienen que poseer un complejo de imágenes animadas por sentimientos. Esta dosificación se da en los poemas de Vestigios porque no se cae en el juego verbal superficial y tampoco en el desahogo fácil o compulsivo: su densidad está construida estéticamente, arquitectura fundamental para que haya poesía. En el libro no hay poemas que se sostengan en estado potencial, virtual, sino por el contrario, todos alcanzan el estado de realización poética. Aquí escribir es resistir, luchar, justificarse, sostenerse en vilo, arrebatarle las trincheras a la muerte, poner el corazón allí donde sudan aceite las máquinas de guerra. Es, en definitiva, hacer historia, documentar, testificar; pero sabemos que hacer historia desde la poesía es algo más exigente y complejo que registrar los acontecimientos externos y objetivos como suele suceder en los textos narrativos condicionados por el positivismo. En el modelo de lenguaje de Vestigios, se plasma el sentido del imaginario histórico-social y se puede dimensionar el real espesor de la identidad del hombre en la cultura brasileña y latinoamericana.

Y es curioso lo que sucede aquí: el significado de la palabra vestigio, trasciende a cada rato hacia su contrario, algo aquí se niega a morir, al menos los pensamientos que se van sedimentando entre escombros y deshechos. El hablante lírico, a través del entretenido diálogo con el lector, no siembra nihilismo ni incertidumbre, a pesar de que la arqueología justifica su acción buscando alguna respuesta categórica a lo que es y ha sido el hombre en su condición existencial.

\section{Primer viaje: el tiempo}

La ausencia de huellas, las marcas corroídas por el tiempo, difusas por la pasión de otras pisadas y andamios, obligan a callar. Algunos se trans- 
forman en nostálgicos; otros, en melancólicos. En el poema "Vestigios", el pasado y el futuro como epigrama de lo imposible, voces antagónicas entre la tradición y el porvenir ¿Qué es el tiempo si no es palpable más allá del huidizo presente, del aquí y del ahora que mira hacia todos los puntos cardinales y donde las sombras vuelven a juntarse en la memoria?:“De algunas cosas no se tienen más vestigios:/ utensilios/ obras/ costumbres/ y sentimientos/ que cayeron en desuso./ Por eso algunos callan/ otros filtran los ojos vagos/ en el horizonte..."10

El poema que abre el horizonte para todos los viajes, eje de esta imagen del tiempo, es precisamente "Todavía es tiempo". Ante las ruinas estamos obligados a callar, a dejar que nuestros ojos y recuerdos repasen la senda por donde el hombre quiso trascender, quiso quedar escrito en alguna parte, decirle a los que vienen en los genes de la fugaz permanencia que todavía hay tiempo para la última celebración, para aceptar la pequeñez y a la vez el lamento por lo que aún no se ha realizado en plenitud. Hay tiempo para entender a los grandes poetas y artistas, voces que le pueden devolver lo robado a la multitud. El inicio del siglo XXI es el ingreso al límite de las posibilidades temporales para rectificar lo que se hizo mal o no se hizo y así esforzarnos en entender la historia: "Todavía hay tiempo/ para entender/ el silencio acre/ de Beckett/la ironía espesa/ de lonesco/y de Kafka/ la sombría alegoría"11.

En el poema "Cambios y retornos" aflora la conciencia del tiempo en la vejez que prepara su despedida; el asidero está depositado en el niño que se lleva durante toda la vida en el corazón de un cuerpo que está terminando su ciclo terrestre. El tiempo ahora se transforma en un nudo que ata el zarpe definitivo en la: "voluntad de regresar y proteger a ese niño,/ Ser su guía o padre, es por aquí/ no pierda el tiempo desafiando el viento,/ enseñarles los senderos invisibles en el desierto"12.

El poema que logra ensamblar vida, amor, muerte y poder, comprendiendo que la sabiduría es la templanza que ayuda a conformarse en los grandes enigmas, es "Cosas antiguas", en el cual desde los babilonios hasta los racionalistas actuales, nobles y plebeyos llegan a las mismas conclusiones que se resumen en metas difíciles de alcanzar como: "conseguir el pan / equilibrar el amor y la muerte/ y constatar/ que el poder/ lleva a algunos a delirar"13.

En "Estoy diciendo para esta lagartija", el tiempo se percibe como una dolencia. Para los animales como lagartijas, arañas y hormigas, pareciera

\footnotetext{
De Sant'Anna, Affonso Romano (2005): Vestígios, RJ, Editora Rocco, página 14. Op.Cit., página 18.

Op., Cit, página 82.

Op., Cit., página 89.
} 
ser indiferente. Los objetos están exentos de tiempo, es el hombre quien los desgasta con la medición de sus "Relojes demás", poema irónico en el cual el hablante lírico se rebela a la excesiva mecánica que lo aplasta y angustia. A pesar de los millones de relojes que existen, siente que llega atrasado para alcanzar la inabarcable eternidad y curarse del virus del hambre de amor. Al interior del hogar, en la quietud del atardecer y de la noche, los relojes dejan de funcionar, pero al despuntar el alba y comenzar el día, se rompe el silencio y la alternativa es naufragio o travesía. Es la agonía que se despliega en el poema "Hay una cierta hora", que es el intento de continuar el viaje hacia el lugar incierto. Ante el despertar que rompe con el silencio, en "Persepolis" el tiempo se manifiesta en las ruinas y la historia se confunde con ella; un eclipse ha escrito en las ruinas la derrota del sol y se ha impuesto el reinado de la luna. Tres diosas contemplan el espectáculo de Sísifo, Varuna "con mil ojos guardando el buen orden", Mitra, "presidiendo las alianzas" y Surya, "el Sol inicial rigiendo el cosmos" donde Zaratustra "el único adolescente que nació sonriendo, sigue dialogando con los astros"14. La pregunta qué es Persépolis pareciera resolverse en el culto a los muertos. En el poema "Partida", se cambian de lugar los referentes vida-muerte como si se alteraran los puntos cardinales del destino. La muerte es llegada y la vida es partida involuntaria, inexorable vestigio de una biología que se esfuma como la belleza o el poder. Se concluye que morir la muerte pura es una dulzura a la cual no hay que temer. Ante la evidencia de este gerundio existencial, en el poema "Tardía juventud", los amores tardíos, los arrepentidos y los culposos llegan tarde a la hora del banquete del amor tal vez perdidos en la otra orilla del río. En los poemas "Catedral revisitada", y "Envejecer", los objetos religiosos parecieran estar detenidos en el tiempo ¿o es el tiempo quien se detiene en los ladrillos de las religiones e irónicamente permite que los feligreses se mueran sin apelación? Una posibilidad de trascendencia es dispersarse en la nada, en esa "Volátil eternidad" que trasuntan las palabras y las oraciones de los fieles en sus letanías por dispersarse por el otro lado del tiempo marcado por los relojes. En el poema "Para Fanny Bracher", es la experiencia del arte quien pareciera resolver todas estas ecuaciones sobre el tiempo. Fanny, al crear sus cuadros ayuda al hablante lírico a salir del tiempo corrosivo y lo desplaza hacia la vivencia de la única sensación de eternidad a la medida de lo humano: la creación artística, donde "Fanny sigue pintando/ sin alardes. Aquí la placidez del tiempo/ se confunde con lo intemporal de la tarde"15.

El ingreso a la vida terrenal es partida involuntaria; la corrosión de lo vivido está sujeta a ese tiempo humano que se acumula en las borrosas huellas del origen. Y la eternidad ¿cómo explicarla o entenderla desde de la palabra coloquial si no reside en ella? 


\section{Segundo viaje: la vida y la muerte}

Tiempo, vida y muerte constituyen la tríada indivisible en la agonía del ser y del estar. Poéticamente no es posible tratar por separada una reflexión que vincule al hablante lírico a la intuición de esta inefable realidad. Desde la verdad de la poesía, todos los viajes son un mismo viaje, un mismo tren que nos "pasea" por el mundo, que muestra lo de fuera, que otorga imágenes de eternidad y simultáneamente saca o aleja al hombre de su vaporosa tendencia de apropiación (cosas, dinero, personas, ideas, poder).

En este viaje se cruza la tradición prerrenacentista con el ethos cultural desvalanceado por la modernidad en la convergencia de las tres tristezas y alegrías brasileñas en un siglo XX, cuya historia es la escritura de la muerte y el intento de matar la poesía. El poema "Diferencias, similitudes", interpela desde las magníficas coplas del poeta español Jorge Manrique a propósito de la muerte de su padre. Aquí la vida es el "río que va a dar a la mar que es el morir". En ella, todos diferentes; en la muerte, todos iguales. La muerte es democrática. El entierro es el momento y el lugar de la indescifrable humillación (a pesar de la pompa de reyes y poderosos por mantener las diferencias para conservar su estado en el más allá). El contrapunto a la tradición manriqueña es el poema "Rio Zayande, quien otorga vida"; este río es el caudal que desciende de las montañas de Irán sin interés de consumirse en el mar. La convergencia es que el río es la vida, pero su divergencia está en concebir una forma de vida que no va a ningún lugar; el desierto es su mar, su destino no es diluirse, sino vivir en los márgenes y fecundar el desierto. Creo que en esta concepción de la vida y de la muerte subyace la influencia de Carlos Drummond de Andrade como poeta gauche, el marginal que fecunda el mundo. Para plasmar esta fecundación, hay que estar fuera del mundo, desde la otra orilla; es la idea de la marginalidad como ausencia que "hace presencia" a través de la actitud consecuente del poeta frente al tiempo que le ha tocado vivir. Sin duda que en este motivo hay un arte poética que se reitera a lo largo del libro: "Es como un tren que pasa/ pero en cada estación que llega/ llega para quedarse./ Así él pasa/y está siempre allá./ Así transitivo/ él es/ -y él está"16.

Y no hay peores formas de morir que los desencuentros y mejores formas de entregarse el uno al otro que dejando de ser lo que ambos son para fundirse en el encuentro amoroso, en el absoluto de lo uno que enmudece a los enamorados en la contemplación de sus silencios. En el poema "Dama de la noche", la mujer es una imaginario vivido en el epicentro del amor y de la muerte que a través del hálito de su perfume

$16 \quad$ Op., Cit., página 58. 
permite evadir la desolación al llegar la madrugada. En "Lapidar una mujer", se denuncia cómo en Nigeria el machismo sacrifica a las mujeres (que luchan por su liberación) y se las obliga a vivir petrificadas porque aún se les considera "imperfectas figuras en el orden de la creación"17. En el capitalismo la mujer es un objeto para burlar la soledad, pero quien está acompañado de su imagen poética como restitución de su dignidad, nunca estará solo. En poemas como "Salomónica", "Caen", "Testamento de Borromini", "No soportando la ansiedad de la muerte", etc., la vida y la muerte es tensión y sufrimiento en la entrega del trabajo, en la solidaridad que salva o arrastra en los remolinos inconmensurables de las aguas. Ante la desesperación, el suicidio paradojalmente se explica cuando la muerte abandona a la vida al romperse su indisolubilidad en su contradictoria manera de conllevar la miseria. En la experiencia colectiva de la sociedad capitalista, la guerra es una especie de deporte de la muerte. Y en el plano personal, la vejez es inexorable, una verdadera invasión sin permiso del hombre. La muerte manda, se impone. En el poema "Testamento", la muerte se acepta como una forma de amar al mundo en la medida que el hablante lírico lo abandona, se retira, lo mira en lontananza. Mientras todo se deslíe, se pregunta qué es la posteridad.

En este viaje por la vida y la muerte está siempre presente el amor vinculado a su proceder oscuro, triste y a veces luminoso; a la indiferencia, distancia, lealtad y traición. Encuentros, desencuentros, humillaciones, silencios impuestos por el cinismo y la hipocresía, dolores propios y ajenos y arrepentimientos son manifestaciones del ser en el tiempo como lo concibe Heidegger. La pregunta queda abierta ¿La eternidad es tan volátil como la posteridad en el leitmotiv de estos viajes?

\section{Tercer viaje: la identidad}

En este viaje hacia la identidad se consignan nueves poemas intitulados "El hombre y su sombra". Pareciera ser que tradición y naturaleza se amalgaman en la mirada del "sí mismo como otro", en el hombre tras el escondite de su máscara, perseguido por su sombra como respuesta a una pregunta que clama por explicarse desde su ensimismamiento, la posibilidad de trascender a su propia interioridad. El hablante lírico se siente como si fuera perro, caballo u hombre con sombra de perro. En la oscuridad, nadie puede dudar o huir de su sombra, pero basta que un rayo de luz perfile los cuerpos para que emane el conflicto, la contradicción, la necesidad de búsqueda de la coherencia entre observación y cosa observada, entre el yo y la conciencia. Si la sombra es blanca, el hombre no se ve, no existe en el conflicto y tampoco el conflicto existe en él.

17 Op., Cit., página 68. 
La sombra se funde con su sombra, se hace en una sola manifestación, circula en su propio anillo en la duplicación que no se ve. De este modo, la identidad se convierte en una obsesión, pero cuando esta identidad se realiza en la plenitud de todo anhelo vivido y compartido, se exhala un perfume que hace agradable la relación sin saber exactamente qué es o quién se es. Entonces se evidencia que la identidad es una sombra escurridiza, un fluir, una movilidad que cambia, un regreso que pugna por ir a los orígenes, la quimera de los primeros días. En esta dialéctica de opacidades y colores, surge la alteridad, lo que (re)coge y explica las identidades de los otros, sus sombras en la realización del yo-individual en el yo-colectivo que habita en la pobreza de las familias latinoamericanas. Los elefantes lloran cuando están enfermos, los hombres se ahogan cuando viven en silencio. Identidad es comunicarse con la sombra toda vez que la palabra se fractura en la necesidad del tener insatisfecho, del hijo que se engendró por fantasía de pasión y que finalmente se constituye en fuente de dolor y sufrimiento. Es la dinámica sombría del sujeto social latinoamericano que vive en búsqueda de su autenticidad y sólo consigue resultados equívocos y promesas incumplidas.

En el poema "Mi ojo está viendo cosas", observando el espacio y la tierra desde el avión que aligera los cuerpos y los torna frágiles en la velocidad del vuelo, el hablante lírico se identifica con la naturaleza y declara que si viviera como sujeto originario en la civilización vegetal no necesitaría ser poeta; es decir, la naturaleza podría definirse como poesía plenamente realizada y en ella las sombras abandonarían la angustia provocada por la vida en la miseria terrestre: "Mi ojo está viendo cosas/ que no se condicen con lo real [...] Visto desde el avión/ el horizonte es curvo/ y viajo en una urna/ que se puede despedazar [...]./ No estoy bien equipado/ para la tarea que me proponen./ no consigo ver con propiedad/ mi limitado horizonte" ${ }^{\prime 18}$

En este viaje por la identidad, las sombras son las dificultades para desentrañar qué es la identidad personal, qué ojo puede tener el ángulo perfecto para indagar qué hay en el lado oscuro de la luz y aceptar la imagen de sí mismo en la construcción que los demás hacen del otro. El hablante lírico aquí no se plantea la identidad cultural como una forma de vivir un problema de correspondencias al interior de un imaginario histórico- social. Los animales pareciera que están más equipados que los hombres porque metafóricamente ven en lo oscuro y no "interpretan el mundo/ ni piensan qué es la historia./ Cazan cuando es necesario/y procrean cuando urge" 19 .

$18 \quad$ Op., Cit., página 77.

19 Op., Cit., página 77. 


\section{Cuarto viaje: el amor}

En este viaje el hablante lírico vuela y se divierte, se alegra y se lamenta en todo tipo de amores y de mujeres sin caer en la lujuria. Son diecinueve poemas que recogen el humor absurdo y picaresco como es el caso del enano de Marrakech que con sus manos vuelve locas a las mujeres; son poemas que comparten el amor que se refocila en el sexo y culmina en el orgasmo como un disolverse en el cautiverio del placer. Los amantes satisfacen sus pasiones con la misma elocuencia con que las flores esparcen sus perfumes. Aquí, la naturaleza triunfa sobre la muerte. Puede haber tristeza, pero no pecado; puede haber conflicto, pero no abandono; pueden haber edades y formas desconcertantes, pero jamás cansancio ni repudio.

En las primeras estaciones de este viaje, el hablante lírico se encuentra con Hafez, el viejo poeta persa de 60 años que se lamenta por enamorarse de una joven y recién entonces llega a comprender que el amor se vive y no se explica. También se sabe de la historia de una mujer que busca un amor después de los 45 años y que se decepciona porque sólo encuentra hombres casados. Los amores tardíos se definen como un mirar desde la otra orilla del río. Y así van aflorando los sentimientos contrariados de los amores inmaduros, neuróticos, superficiales y adolescentes: "Como es difícil (y raro) el amor/ el amor y su construcción/ el amor y su manutención/ el amor del cual tanto carecemos/ y del que tanto hablamos sobre el que/ tanto escribimos el amor que viví antes/ el amor que ahora siento/ antes/y después / de los $45^{\prime 20}$.

En otros andenes, mujeres desamadas saben conversar y entretener como ocurre en el poema "Balada de las jóvenes de mi calle": Teresitas, Silvias, Clarizas, Lucías, Estelas y Helenas saben practicar la compañía del amor circunstancial. Son los tiempos sucesivos y perdidos a través de muchos amores arrepentidos que no supieron enmendar su erotismo ¿Qué son los amantes ocasionales que vienen y se van? Algo semejante al milagro del placer que se torna jubiloso en el rostro de la mujer. El amor alborozado es aéreo, volátil, aleteo hacia el espacio del no-lugar. Y así se avanza hacia el amor-pasión, inseparable como el rayo del trueno y como el sudor de la satisfacción. En el poema "Amor o abismo" emerge la mujer que ama en los límites del caos y culmina en el canibalismo de la "Organización de los placeres". Las mujeres cultas y de clase alta también practican el amor furtivo y hablan banalidades a pesar de conocer a Platón, Hegel, Nietzsche y Kafka. En las mujeres finas como Enriqueta Lisboa, se reconoce que en ellas "la poesía es la forma de rozar las alas en el infinito. En el poema "En el mejor de los casos", se formula qué es el

$20 \quad$ Op., Cit., página 88. 
orgasmo en esta ingravidez que alcanza el amor enamorado: “. .. amorosamente disolverse en ella/ como ciertas flores al viento/ en un alarido/ que no se sabe si es de placer/ o es lamento"21.

Y a base de estos encuentros, en "Astronomía amorosa", el hablante lírico concluye que en el sexo de la mujer amada, además de lenguas, ojos, senos, nalgas y pantorrillas, hay una constelación de estrellas, la galaxia entera. Es a la entrada de esta galaxia donde las manos del enano de Marrakech "tocan, rozan, no hieren e imperan" y hacen que las mujeres queden suspendidas en el aire hasta "trascender en el espiral de las delicias".

\section{Quinto viaje: el conocimiento}

En este viaje, uno de los más cortos pero abisales, acompañan al hablante lírico una serie de pasajeros que portan en su equipaje la experiencia, el amor, la muerte y la participación política transformada en tragedia social. Reconoce que es terrible pensar en la existencia de mujeres terroristas y de hombres-bombas arrastrados por la compulsión de su desasosiego, suerte o azar a la destrucción de su quimérica libertad que los griegos Ilamaban tragedia. Es terrible saber que "ya algo está en movimiento/ y no hay manera de parar"22

Filósofos como Kant y otros hombres del conocimiento que son capaces de pensar profundidades y alturas, también estudian la naturaleza en sus manifestaciones telúricas que a veces se transforman en maldiciones para el hombre ¿Lo que se ve y se vive es falso o verdadero? ¿Por qué quien posee belleza atrae tanto? ¿Será porque la belleza tiene luz propia y nadie se puede restar a su sombra inexistente? ¿Cómo explicar el crepúsculo si uno no es embobado por la naturaleza? Pareciera que todo depende del modo de vivir las cosas o del hecho de no poder inventar. En la sabiduría china alguien se ríe de las esperanzas muertas. Estas preguntas se responden o se tornan más crípticas en el poema sobre las adivinanzas para saber qué es el amor, el heroísmo, el amor abstracto y real, comprender por qué el amor es un vicio que llega al suplicio y por qué el médico no tiene medicamento para la muerte.

Este viaje el conocimiento es más ontológico que gnoseológica sin evadir las circunstancias concretas donde el amor deja atisbos al avanzar allí donde la inteligencia y la razón no alcanzan a trepar. Esta forma de conocimiento nos hace recordar al poeta chileno Gonzalo Rojas cuando

$21 \quad$ Op., Cit., página 189

22 Op. Cit., página125. 
se pregunta “¿Qué se ama cuando se ama, mi Dios: la luz terrible de la vida/ o la luz de la muerte? ¿Qué se busca, qué se halla, qué/ es eso: amor? ¿Qué es? ¿La mujer con su hondura, sus rosas,/ sus volcanes/ o este sol colorado que es mi sangre furiosa/ cuando entro en ella hasta la últimas raíces? ${ }^{23}$.

\section{Sexto viaje: la trascendencia religiosa}

Nuevamente desde el aire, el hablante lírico en el poema "Allá arriba", se pregunta dónde se encuentra Dios, si en las alturas o en las ruinas ¿Todo lo que hace el hombre en su cultura, como lo asevera Walter Benjamin en su Filosofía de la Historia, es documento de barbarie? Más adelante, en "Pérdidas poéticas", el hablante lírico siente que no escribir los poemas que vienen del corazón a la cabeza son un desgarro, una pérdida del vínculo sagrado, aquello que no tiene precio para una vida verdadera. Entonces, la peor desidia es no responder a los llamados interiores. Si se actuara siempre con desgano, el hablante lírico llegaría a transformarse en objeto religioso detenido en el tiempo como sucede al contemplar la "Catedral revisitada": "25 años después, esa catedral/ todavía me alucina y giro en torno a ella/ con mi alma peregrina./ No vengo de las cruzadas y no hago penitencias/ no soy siquiera más creyente./ Sin embargo aquí estoy (extraño destino)"24. De algún modo se percibe que la poesía es también un acto de fe alejado del poder y de aquello que la Biblia tal vez no previó. En el poema "Tentaciones" se constata que Cristo rechazó, igual que la poesía, la tentación del poder, no bebió el cáliz del poder: "A Cristo le ofrecieron la gloria humana/tres veces sobre el templo/ -él la rechazó/ A Julio César en tres ocasiones/ le trajeron la corona/ -él la rechazó/ Al poeta le trajeron la máquina del mundo/ sus secretos y maravillas/ -él la rechazó/ La llave del templo-tiempo/ la corona del imperio/ la máquina del mundo/ Alejen de mí ése cáliz/ (y cayó)"25. Ante las interrogantes que provienen de la Biblia, sus historias, consuelos y esperanzas, el hablante lírico se pregunta por qué la condición humana es la misma desde hace miles de años ¿Acaso es estática, jamás el hombre cambiará? ¿Nunca evolucionará para mejorar en sus propias expectativas? ¿Su alma no es más que un trozo de hielo que irradia un falso calor? ¿Qué es lo que la Biblia no previó? “Que algunas especies se transformarían./ No obstante, como electrodomésticos/ automóviles y la moda que se renueva cada año/ algunas especies se están modernizando./ La verdad es que las baratas y las hormigas/ parecen no haber cambiado/ delante del milenario

23 Primera estrofa del poema "¿Qué se ama cuando se ama?" de Gonzalo Rojas en Las Hermosas (antología), segunda edición de 1996, Editorial Los Andes, página 143.

24 De Sant'Anna, Affonso Romano (2005): Vestígios, RJ., Editora Rocco, página 146.

25 OP., Cit., página 181. 
mirar de los hombres./ ¿Pero si las especies se están transformando/ por qué desde hace seis mil años/ leo en los periódicos/ y no veo mejoría alguna/ en la esencia del ser humano?"26.

En consecuencia, en este sexto viaje se busca a Dios en el tiempo y en las ruinas como tiempo desmoronado. Se recuerda que el mérito de Cristo fue rechazar el poder. Más que lucubrar en una metafísica, aquí estamos nuevamente en presencia de una ontología en medio del discurso de una historia de tentaciones. Persiste la pregunta ¿La condición humana es estática, el hombre jamás superará su miseria?

\section{Séptimo viaje: la naturaleza de la historia}

En este viaje, probablemente el más seductor y a la vez el más doloroso de todos, el hablante lírico verifica las hipótesis del poder, se pregunta para qué sirve la tentación del mando, por qué el hombre convencido del valor de la solidaridad y de la cooperación, noche y día se perturba al imponer la fuerza allí donde la humanización comienza en la razón para refrendarse en el venturoso lenguaje del arte y de la poesía. A través de diecinueve poemas, la historia se escribe en lenguaje de escombros, en la huida del animal que abandona para siempre su territorio, en el pájaro mecánico que entra al corazón del imperio, destruye cinematográficamente sus signos de poder y de dinero y nos recuerda que todo imperio es vulnerable.

El poema "Pasárgada" es la imagen de signos, huellas y señales donde la poesía pareciera reinar en fantasmagórica ausencia. Donde no hay poesía, hay pasárgada: "Aquí yace el rey de los reyes/ cuyo imperio de Babilonia a Etiopía/ de Afganistán a Capadocia/ ahí donde sus arqueros y caballos/ llegasen [....]/ Adelante/ entre ruinas/ está Pasárgada./ ¿Dónde el ruido de los escudos/ el atropello de las patas de los corceles en guerra/ el alarido de las lanzas / los sones de los instrumentos en fiesta/ resonando en las acequias/ chorreando en los jardines?"27. Este pasaje se reitera en el poema "Sobre los ríos de Babilonia" , simbolizando la caída de la gran ciudad donde se llora de impotencia y humillación "sobre el Tigre y el Éufrates/ sobre el Mississipi y el Támesis/ sobre el Amazonas y el Nilo/ sobre el Volga y el Danubio"28. Ante este panorama de ciudad, el desamparo se incrusta en el corazón y se experimenta la necesidad de recuperar al niño que cada uno guarda, ese que ante el espectáculo de la destrucción se reconoce y se busca como si fuera el padre que está

\footnotetext{
Op., Cit., página 168.

Op.,Cit., página 48.

Op., Cit., página 55.
} 
por volver. Nada es más nefasto que la sed de oro y gloria como lo fue el periodo de la Colonia. En el "Poema sacado de un manual de historia", se atestigua que todo es posible porque "El alma humana es fracaso y callejera/ peleando entre las visiones y la ceguera..."29.

En "Indagaciones de John Ruskin", el hablante lírico se pregunta qué queda de todo lo vivido: "Quién, en medio de la multitud charlatana/ me podrá hablar de las formas y de los precipicios/ de la cadena de altas montañas blancas/ que ciñen el horizonte hoy a medio día?"30. En "La Grecia posible", poema en cuatro actos, los paisajes dejan entrever que las ruinas sólo permiten evocar aquello que los hombres depositan en la memoria y que al pasar los años se trasmuta en nostalgia. Tiembla la imaginación al constatar que las ruinas no permiten recapturar lo que fue aquella realidad, ese pasado en el palacio de Agamenón.

En los poemas "La fiesta y los reyes" y en "11.9.2002", el siglo XX aparece como el hito más grotesco de las manipulaciones de poder en medio de la fragilidad de las naciones más poderosas de la tierra. Ante las abominables costumbres de los "reyes" que dominan el mundo de ayer y de hoy (los aborrecidos de siempre legitimados por el miedo y la mentira), pareciera ser que los llamados cambios civilizatorios y los pomposos "nuevos paradigmas", en nada han mellado la desfachatez, el fetichismo y tampoco mermado el grado de estupidez de aquellos que "representan" el destino de la humanidad en las democracias liberales occidentales. Sin duda que la destrucción de las Torres Gemelas en el corazón del imperio norteamericano, vaticina el desmoronamiento de una civilización racionalista y pragmática cada día más quimérica para sus propios ciudadanos: "Cayó, cayó/ como cae/ lo que nunca/ caería./ Cayó/ en la caída/ que apenas/ comienza" ${ }^{31}$.

En este viaje por la naturaleza de la historia, la actualidad se explica mirando de manera retrospectiva y crítica el pasado. Tiberio y sus sucesores que hicieron del siglo XX un campo de concentración y de muerte, en la inversión temporal de los acontecimientos, ya poco pueden influir para cambiar el curso de las cosas. Felizmente la poesía no se da por vencida. 


\section{Octavo viaje: la política en tolerancia y solidaridad}

En este viaje la política es oportuna y necesaria como la primavera, aunque siempre el lobo del capitalismo tiene sus fauces abiertas, haciendo lo posible y permanente para engullirse a esperanzados y audaces luchadores por la democracia.

En el poema "La primera vez que entendí", el hablante lírico explica qué es el mundo a través de la imagen de una lagartija. Al ver que ella y su cola cortada seguían moviéndose, comprende por qué el mundo es dinámico; comprende por qué el amor no termina mal a pesar de la dificultad para extirpar el mal de raíz. A partir de la incógnita de las tres certezas que perdió en la adolescencia, sigue adelante descifrando mensajes y buscando el rumbo en la oscuridad, en las nubes o en los rayados de los muros de la ciudad. Esta asociación lo lleva irónicamente a recorrer oficinas, gobiernos y cócteles, lugares en los cuales los políticos suelen metamorfosearse en reptiles. No es ninguna garantía para que resuelva bien sus diferencias, que el hombre esté dotado de cerebro y médula espinal como los animales; a lo más, serán órganos suficientes para que marche ordenadamente en fila.

En el poema "El hombre-bomba", uno de los más patéticos del libro, se plantea por qué esta opción de transformarse en gatillo de la muerte para arribar a un destino incierto. El hombre suicida que porta explosivos para destruir y mutilarse, carece de explicación racional o es simplemente un enigma para la inteligencia y la conciencia toda vez que una "convicción", un credo, la razón de la sin razón que lo convierte en terrorista, activa los mecanismos de su contradictoria e insoportable humanidad ¿Presos de este fenómeno fueron los pilotos suicidas que estrellaron los aviones contra las Torres Gemelas en la ciudad de New York? ¿A tanta nulidad de la inteligencia puede llegar una convicción? ¿O son las ideas, en ciertas circunstancias, las enfermedades incurables del cerebro? Desde entonces lo impensable es pensable; la utopía, la fe y la obediencia a una deidad que rompe los ojos atiborrada en el más desastroso porrazo hacia la nada, "como el narrador/ que por el fin/ cuenta su trayectoria/ y el autor/ que pusiese el epílogo/ en lugar del prefacio./ El hombre-bomba/ no es un simple suicida/ es aquel que a través de la muerte/ decide/ inaugurar su vida" ${ }^{32}$ ¿Cómo los demás podrían protegerse de estas conductas? En las aduanas, ni los mejores policías del mundo, pueden quitar lo que se lleva asimilado en el cuerpo, lo que es sangre y palabra, la ecuación que se resuelve en la distorsionada frase del "ser-para-la-muerte". En este con-

$32 \quad$ Op., Cit., página 64. 
texto ¿quién es el ilustre fracasado, el decepcionado de ser hombre? En el poema "Tengo oído sobre mis historias", el hablante lírico señala que "es todo falso o verdadero/ dependiendo/ de modo intenso/ de vivir las cosas/ o/ no pudiendo/ inventar" ${ }^{33}$ ¿Cuál sería la solución para extirpar el mal? ¿Sacar de la sociedad a los "drogados, suicidas, guerrilleros muertos, fracasados, canallas, degradados" ${ }^{\prime 34}$. Como afirma el tío Ernesto en el poema "Sabiduría de la edad": el mundo es de los audaces. Bajo estas sombras leo el poema "Brasil" que dice desde el desasosiego: "Llaman a esto país/ cuando es apenas/ una herida abierta/ en mi pecho/ que intento cicatrizar/ pero no tengo manera" ${ }^{\prime 35}$.

Este viaje concluye evocando a Neruda, quien "florece en el relámpago del riesgo" ${ }^{\prime 36}$, asociando la libertad con la primavera que es capaz de florecer hasta en la boca del lobo: "como la luz de la noche y del día/ la libertad/ llega en horas diversas en cada punto del globo./ Pero es sorprendente/ que no pidan permiso para florecer las flores/ o algunas florezcan/ en la boca del lobo" ${ }^{\prime 37}$. La sabiduría de la inteligencia política sólo se resuelve y se resume en tolerancia, la solidaridad y en esas cosas difíciles de alcanzar, como "conseguir la casa y el pan/ equilibrar el amor y la muerte/y constatar/ que el poder/ conduce a algunos al delirio./ Cosas así, tan domésticas/ que nos toman la vida entera/ no para entender/ -para aceptar"38.

\section{Noveno viaje: el arte contemporáneo}

Este viaje está refrendado por las luces y sombras que convergen en la evaluación del arte contemporáneo. Las palabras clave en el poema "Cuando Caravaggio descubrió la luz", son luz, claro, oscuro y pintura. Su motivo significa que ser auténticos implica alejarse de influencias, dejar de transitar por caminos conocidos, buscar nuevos derroteros allí donde el color y la forma no han perdido el rumbo

Chagall, con su hiperbólica mano, ha inventado el mundo siete veces: "de esa mano/salían vacas y cabras levitando/ esposos aéreos bailando/ soldados sacerdotes campesinos/ músicos planeando/ sinagogas incendiándose"39. En el poema "Anotaciones en un cuaderno de viaje", el

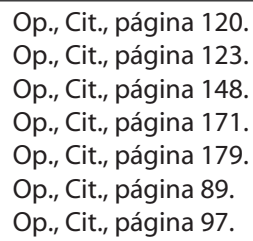


hablante lírico descubre la importancia de ver por los ojos de Brueghel y de Cranach.

En el poema "Galería nacional de Londres", el hablante lírico sella su distancia con Duchamp: "Estoy delante de la Batalla de San Romano de Paolo Uccelo./ Y exijo respeto./ No me vengan a hablar/ de Marcel Duchamp"40. Y ante ese "Esa María Magdalena", cuadro de Perugino, aprecia que su calidad estética y fuerza erótica exhala deseo y olor. Picarescamente concluye el poema diciendo "en fin/ ahora entiendo/-lo que en ella vio Nuestro Señor" ${ }^{41}$.

Este viaje tan distante del país natal, concluye con el poema "Piranesi", cuyo cuadro sugiere cómo el arte puede hacer de las ruinas la fuente de recuperación de la vida: "Otros pintaban/ lo que resplandecía/ él/ se aplicaba a las ruinas:/ columnas partidas/ sarcófagos/ árboles carcomidos/ serpientes y prisiones oscuras/ desolados paisajes/ de Roma antigua/ Fue allí/ en las ruinas/ que Piranesi/ observando la vida/ hizo sus obras-primas"42.

\section{Décimo viaje: la poesía}

Desde los polos de su contradicción y conflictos vitales, el hablante lírico en el poema "Misterioso conjunto", parte diciendo que no es un iluminado ni un sabe-lo-todo, sino un hombre razonable ¿Qué somos los hombres? "-Separados o juntos/ somos apenas parte/ de un misterioso conjunto" ${ }^{\prime 43}$. Refrenda irónicamente estas contradicciones recordándonos la forma de vivir y de morir del poeta João Cabral de Melo Neto, quien se fue de esta vida al revés de todo lo que había anhelado y rechazado. Ante estas formas que cobra el destino, sin duda que es mejor reírse: "El poeta João Cabral de Melo Neto/ áspera piedra nordestina/ severísimo cultor de la forma/ ateo/ abominaba derramamientos líricos y sentimentales./ No obstante esto, era académico/ no obstante esto, era diplomático/ no obstante esto, murió rezando/ y su cuerpo/ fue velado en el Salón de los Poetas Románticos"44. Pero en el poema "El silencio de Rimbaud", se pregunta en la penúltima estrofa ¿qué es más poético, la obra o el silencio patético del autor? "-hasta qué punto/ el silencio hace hablar/lo que la obra silenció" 45

\footnotetext{
Op., Cit., página 99.

Op., Cit., página 100.

Op., Cit., página 101.

Op., Cit., página 7.

Op., Cit., página 93.

Op., Cit., página 94.
} 
En el poema "Tres veces João", referido a Guimarães Rosa, confirma que la poesía, sustrato de su gran narrativa, es la luminosidad musical del idioma: "João Guimarães Rosa/ escribió su sigla JGR/ en medio del sumario alfabético de Tutaméia/ siendo cada letra la inicial de un cuento:/ João Porém/ o criador de perus/ Grande Gedeão/ Redminição"46. Y recordando a Ovidio en su Arte de Amar y leyendo sus cartas, advierte que "no hay obra literaria/ sin riesgo para el lector/ ¿Cómo puede uno saber/ si las viudas y las matronas/ han de leer mis simples versos/ con segundas intenciones?"47.

Culmina este viaje en los cuatro movimientos del poema "Wittgensteinianas", donde ya no es separable la palabra coloquial, de la palabra poética y de la palabra filosófica. Aparentemente es un juego de oposiciones y sentidos, donde la indagación del creador pretende ir más allá de las ironías consigo mismo. En la wittgensteiniana 1, se pregunta qué es el sentido: ¿Qué es el sentido de una palabra?/ ¿Qué es la explicación del sentido de una palabra?/ ¿Qué es el sentido?/ ¿Qué es?/ 0"48 Luego, en la wittgensteiniana 2, señala que el filósofo del Tractatus logicus philosophicus, llegó a la duda por los colores y a las certezas por las dudas. En la wittgensteiniana 3, nos recuerda que escribió su Tractatus en las trincheras austriacas durante la segunda guerra mundial. Y en la wittgensteiniana 4, nos recuerda que el filósofo solía guardar silencio pensando en el suicidio y que desde pequeño tuvo interés por los objetos voladores ¿Es el poeta un filósofo práctico para el cual la lingüística no es auxilio? Pareciera que en el poema "Delicadeza de ser buey" está la respuestas a qué es el poeta, la poesía y la vida: "Poesía -imponderable digestión:/ lo que queda/del drama que nos vivió/ lo que queda en el cielo de la boca/ del tiempo que nos comió./ En la poesía-memoria/ regurgitando lo que fui/ puedo aquilatar/ la delicadeza de ser buey"49.

\section{Conclusiones}

Los principales movimientos poéticos que se registran en Brasil durante el siglo XX son: Modernismo (1922); Generación del 45, Concretismo (1956); Neoconcretismo (1959); Tendencia (al cual adscribe inicialmente Affonso Romano de Sant'Anna y promueve la revista "Tendencia" que dura hasta 1962), Praxis (1962); Guitarra de la calle y música popular (1967-1973), movimiento que vincula la moderna poesía brasileña a la música. En su seno, Affonso Romano de Sant'Anna participa con Caetano

\footnotetext{
Op., Cit., página 30.

Op., Cit., página 73.

Op., Cit., página 80.

Op., Cit., página 109.
} 
y Chico Buarque de Hollanda). Otros movimientos de fin de siglo serán Poema proceso (1967); Tropicalismo (1968); Posvanguardia y Marginalia (1973), etc.

El nombre de Affonso Romano de Sant'Anna, por el desarrollo de su acción artística, capacidad teórica, propuesta poética-epistémica de orden culto y popular, su creación caósmica traducida en obras y labor pedagógica, está considerado en la lista de los poetas relevantes de Brasil durante el siglo XX; entre otros, Manuel Bandeira, Carlos Drummond de Andrade, Jorge de Lima, Cecília Meirelles, João Cabral de Melo Neto, Ferreira Gullar, Vinícius de Moraes, Paulo Mendes Campos, Thiago de Mello, etc.

Vestigios es el libro de madurez de un poeta auténtico, en el cual se decanta, a través de lo que he sistematizado a lo largo de los diez viajes que hemos podido compartir en esta lectura, una hermenéutica que se configura al interior de un Proyecto Poético Pensante, enraizado, basado en un lenguaje figurativo-práctico como aporte a las formas de "pensamiento complejo" que residen en la poesía. En la realidad terrestre y cósmica todo está junto y separado, a la vez todo se atrae y se repulsa, se cruza, se llama y se niega. La dinámica del caosmos está presente en esta y en el conjunto de su obra: rescate del caos para abarcarlo poéticamente en todos los ámbitos de la experiencia humana. Los viajes de mi lectura se pueden resumir diciendo que la poesía, desde las ruinas y de la oscuridad histórica en que vivimos, tiene la capacidad para recuperar la vida que se nos ha perdido en el machismo petrificador de mujeres, en la civilización vegetal como poesía alguna vez realizada, en el amor disuelto en el cautiverio del placer, en la política que algún día no fue organización de la guerra, en ese Jesús de carne y hueso que no bebió el cáliz del poder, en la naturaleza de la historia que nos hizo creer en los sueños, en el arte como energía renovadora de la condición humana y en la luminosidad musical de los idiomas que residen en las grandes obras en prosa y en verso ¿Hay que volver al origen?

En Vestigios, el hablante lírico vierte y subvierte la experiencia del crítico de arte y a la vez recoge la tradición de los poetas gauche, del que se sitúa en "la tercera orilla del río" de la sensibilidad literaria brasileña del siglo XX. Toma distancia, se aparta sutilmente de los caminos recorridos, ensaya nuevas perspectivas para observar la realidad desde una nueva pedagogía del mirar. Creo que no es exagerado afirmar que Vestigios es un libro que refrenda muchos de los pensamientos de Adgard Morin en Amor, poesía y sabiduría (1998); ayuda al lector a superar las cegueras del conocimiento y enseña a pensar sobre la condición humana en la época capitalista (neo)liberal globalizada que ha sumido a la humanidad en la anomia ética y estética. En medio de la decadencia, el demens; en medio de la sabiduría y la cordura de la poesía, el sapiens. 


\section{Bibliografía}

Bandeira, Manuel (1951): "Panorama de la poesía brasileña", páginas 1-118, en Panorama de la poesía brasileña, antología, $2^{a}$ edición en español. México, Editorial Fondo de Cultura Económica (Trad. de Ernestina de Champourcín).

Bosi, Alfredo (1994): $\quad$ História concisa da literatura brasileira, 38a edição. São Paulo, Editora Cultrix Ltda.

(2002): "Poesia no ar", página 8, em Jornal de Porto Alegre Zero Hora, segundo caderno, entrevista de Susana Vernieri.

Coutinho, Afrânio, de Faria Coutinho, Eduardo (1996):

A Literatura no Brasil, Vol. 6. São Paulo, Global Editora E.

Costa, Horácio (1998): Mar abierto, ensayos sobre literatura brasileña, portuguesa e hispanoamericana. México, Editorial Fondo de Cultura Económica.

Crespo, Ángel (1973): $\quad$ Antología de la poesía brasileña, desde el romanticismo a la generación del cuarenta y cinco. Barcelona, Editorial Seix Barral (Trad. de A.C).

de Sant'Anna, Affonso Romano (2005):

Vestígios. Rio de Janeiro, Editora Rocco Ltda. 197 páginas.

(2004): "Por que a peripecia do poeta "gauche" nos comove", páginas 11-32, en Murilo, Cecília e Drummond, 100 anos com Deus na poesía brasileira. Eliana Yunes y Maria Clara Bingemer, organizadoras. São Paulo, Edições Loyola.

(2004): Poesia reunida, 1965-1999, Vols I e II. Porto Alegre, editora L\&PM.

(2004): $\quad$ Música Popular e Moderna Poesia Brasileira. São Paulo, Editora Landmark

(2005): "O erotismo nos deixa gauche", páginas 11-14, prólogo a O amor natural do livro de Carlos Drummond de Andrade. 14a edição. Saõ Paulo, Editora Record.

(2003): Desconstruir Duchamp, 1 1a reimpressão. Rio de Janeiro, vieira \&lent casa editoria Itda.

(2005): "Brasil-Chile, Ontem e hoje", páginas 320- 
330, en Revista de Literatura y Lingüística $\mathrm{N}^{\circ}$ 16, Departamento de Humanidades de la Universidad Católica Silva Henríquez. Chile.

Jozef, Bella (1995):

Antología general de la literatura brasileña. México, editorial Fondo de Cultura Económica.

Rodrigues Vilaça, Marcos Vinicios (2006):

Posse, Presidência, Academia Brasileira de Letras. Rio de janeiro, impresso na UCLA editora, 71 páginas.

Werneck Sodré, Nelson (1976):

História da literatura brasileira, seus fundamentos económicos. $6^{\text {a }}$ edição. Rio de Janeiro, Editora Civilização Brasileira. 